\title{
CD2 Gene
}

National Cancer Institute

\section{Source}

National Cancer Institute. CD2 Gene. NCI Thesaurus. Code C21361.

This gene is involved in T-cell activation and immune recognition. 